\title{
Contracts for the International Sale of Goods
}

\author{
Recent Developments at the International and European Level
}

\author{
S.A. Kruisinga*
}

\section{Introduction}

In the globalizing economy, national borders seem to have disappeared. However, when determining which law will apply to a commercial transaction, the opposite is true. This paper will illustrate the relevance of national borders for ascertaining the applicable legal regime for contracts for the international sale of goods. In 1980, the UN Convention on Contracts for the International Sale of Goods (hereafter the CISG) was specifically drafted to apply to contracts for the international sale of goods. Recently, the European Commission also published a document containing provisions that can apply to contracts for the international sale of goods. On 11 October 2011, the European Commission published a Proposal for a Regulation on a Common European Sales Law (hereafter referred to as the Regulation on CESL). ${ }^{1}$ If the Regulation on CESL enters into force, crossborder contracts for the sale of goods concluded between businesses within Europe can be governed by the CISG, the CESL and/or national contract law. Thus, these different systems of law may become each other's competitors. Therefore, it is interesting to compare the scope of application of these two instruments and also to compare the CESL with the CISG in order to ascertain which provisions are most suitable for commercial transactions (section 2). It would, however, be going beyond the scope of this contribution to make a complete comparison of the two instruments. From the perspective of private international law, it is important to ascertain whether a contract contains a valid choice of law clause and/or a forum selection clause or an arbitration clause. Such clauses are very often found in standard terms and conditions. Therefore, it is interesting to compare the regulation of standard terms in the CISG and the CESL. This paper will provide a comparison in this respect (section 3 ). It should be noted that this paper does not intend to discuss the validity of choice of law and dispute settlement clauses in general.

Dr. S.A. Kruisinga is Associate Professor at the Molengraaff Institute of Private Law, Utrecht University, the Netherlands.

1. Proposal for a Regulation of the European Parliament and of the Council on a Common European Sales Law, Brussels 11 October 2011, $\operatorname{COM}(2011) 635$ final.
In addition, if it turns out that the contracting parties have not validly incorporated a dispute settlement clause in their contract, the EU Regulation on jurisdiction and the recognition and enforcement of judgments in civil and commercial matters (Brussels I) ${ }^{2}$ may be of relevance to determine which court within the European Union has jurisdiction to hear a dispute in a certain case. The provisions in this Regulation which are of relevance for contracts for the international sale of goods which do not contain a valid dispute settlement clause will be addressed as well as the relevant recent case law by the Court of Justice of the European Union (section 4).

\section{The Scope of Application of the Regulation on a Common European Sales Law (Opting in) and the CISG (Opting out)}

The CISG will generally apply to contracts for the international sale of goods if the contracting parties, i.e. the buyer and the seller, have their places of business in different states. Even though the CISG does not provide a definition of a sales contract, a description of a sales contract can be derived from Articles. 30 and 53 CISG. Accordingly, sales contracts can be described as reciprocal contracts directed at the exchange of goods against a price. In general, the Convention only applies to contracts for the sale of movable goods. According to Article 3(1) CISG, a sales contract governed by the CISG can entail both the delivery of goods and the provision of services: contracts for the supply of goods to be manufactured or produced are to be considered as sales, unless the party who orders the goods undertakes to supply a substantial part of the materials necessary for such manufacture or production. Furthermore, the CISG will also apply to a contract that involves both the sale of goods and the provision of services, unless the preponderant part of the obligations of the purported

Council Regulation (EC) No. 44/2001 of 22 December 2000 on jurisdiction and the recognition and enforcement of judgments in civil and commercial matters. 
seller consists of the supply of labour or other services (Article 3(2) CISG).

The Convention provides that it will apply if both states where the buyer and seller have their respective places of business are Contracting States (Article 1(1)(a) CISG). Almost all EU Member States are Contracting States to the CISG, except for the United Kingdom, Ireland, Portugal and Malta. ${ }^{3}$ Thus, to most contracts for the sale of goods within the EU, the Convention will apply. It should be noted, however, that the Convention does not in principle apply to consumer sales (Article 2(a) CISG). The CISG will also apply when the rules of private international law lead to the application of the law of a Contracting State (Article 1(1)(b) CISG). The contracting parties may agree to (completely or partly) exclude the application of the CISG (Article 6 CISG). The question may arise whether a choice of law clause, referring to the law of a Contracting State, implies an exclusion of the CISG. The majority view in both the legal literature and in the case law is that a choice of law clause that refers to the law of a Contracting State will lead to the application of the CISG. ${ }^{4}$ This may be different if the respective choice of law clause expressly refers to the application of the national law of a Contracting State. ${ }^{5}$ In this context, it is relevant to note that the party who claims the exclusion of the CISG will bear the burden of proof for such an interpretation.

It may be doubted whether, alongside the CISG, an additional instrument of contract law would be necessary. The European Commission gave three reasons as to why the CISG would not suffice. ${ }^{6}$ First of all, the CISG regulates certain aspects of contracts for the sale of goods but also leaves matters outside its scope, such as unfair contract terms and prescription. While this is true, it should also be mentioned that the CESL does not regulate all legal aspects of a contract for the sale of goods either; for example, it does not regulate set-off, representation and plurality of debtors. ${ }^{7}$ Secondly, not all Member States have ratified the CISG. However, as was stated supra, the majority of the EU Member States have ratified the CISG. Thirdly, there is no mechanism which could ensure a uniform interpretation of the CISG. Even though there is no supranational court which can safeguard its uniform interpretation, this does not mean that there is no uniformity in the application of the convention. ${ }^{8}$ There are a number of initiatives which promote the uniform interpretation of the convention. One of the most important initiatives is the establishment of the CISG Advisory Council (here- after the CISG-AC). ${ }^{9}$ This is a private initiative by scholars to promote a uniform interpretation of the CISG; it does so by issuing opinions relating to the interpretation and application of the CISG. Quite recently, the CISG-AC published an Opinion on the incorporation of standard terms, which will be discussed hereafter (section 3).

For these reasons, the European Commission stated that the CISG does not suffice within the EU. When the European Commission published its Proposal for a Regulation on a Common European Sales Law, it stated that the divergences between national contract laws constitute an obstacle to cross-border transactions and impede the functioning of the internal market. Therefore, the objective of this proposal is to "improve the conditions for the establishment and the functioning of the internal market by making available a uniform set of contract law rules" (Article 1 of the Regulation on CESL).

The proposed Regulation itself provides for the scope of application of the instrument. The provisions of the proposed instrument of European contract law (hereafter referred to as the Common European Sales Law or CESL) are to be found in Annex I. In September 2013, the Legal Affairs Committee of the European Parliament approved the text of this proposal with a number of amendments, the most important being to limit the scope of application of the Regulation to distance contracts, notably online contracts. On 26 February 2014, the European Parliament backed this proposal with the suggested amendments. ${ }^{10}$ The next step in the legislative procedure (co-decision) is that the proposed Regulation will have to be adopted by the Council of Ministers. At this moment (July 2014), it is not certain whether the Council will adopt the proposed Regulation.

In general, one can say that the publication of the proposed Regulation has led to different responses; some authors discuss the CESL with scepticism. ${ }^{11}$ Other authors promote a revision of the text of the Proposal. ${ }^{12}$ The German Federal Bar ${ }^{13}$ recommends for B2B contracts to include the CISG in the CESL without any change and to include additional provisions on questions which are not regulated by the CISG. Both the UK Law Commission and the European Law Institute (hereafter ELI) have reviewed the text of the Proposal in a critical

3. See: <www.uncitral.org/uncitral/en/uncitral_texts/sale_goods/1980CISG_ status.html> (last accessed on 16 July 2014).

Schwenzer \& Hachem 2010, pp. 108-111; Mistelis 2011, pp. 104-106

Compare Schlechtriem \& Butler 2009, p. 19.

Proposal for a Regulation of the European Parliament and of the Council on a Common European Sales Law, Brussels 11 October 2011, $\operatorname{COM}(2011) 635$ final, p. 5. See also on this issue: Kornet 2012, pp. 171-175; Kruisinga 2013, pp. 344 et seq.

7. See Art. 11a subsection 2 of the Proposal for a Regulation on a Common European Sales Law.

8. Kieninger 2012, p. 227.

9. See <www.cisgac.com> and Schwenzer \& Hachem 2010, pp. 124-127.

10. See <www.europa.eu/rapid/press-release_MEMO-14-137_en.htm> (last accessed on 16 July 2014).

11. See, for example, Mankowski 2012, p. 45.

12. See, for example, Piltz 2012, p. 133.

13. See "Stellungnahme der Bundesrechtsanwaltskammer", 3 Internationales Handelsrecht 2012, p. 53. A similar comment was made by Lando 2011, p. 722 
and constructive manner and have suggested a number of revisions. ${ }^{14}$

The rules in the CESL can apply to cross-border transactions for the sale of goods, for the supply of digital content and for related services. ${ }^{15}$ Article 1 of the Regulation on CESL states that the rules in the CESL will apply "where the parties to a contract agree to do so". Thus, the CESL has the form of an optional instrument and can be chosen by businesses and consumers to serve as a basis for their transactions ('opting in'). This optional instrument is supposed to be a second legal regime in each Member State, thus providing parties with an option between two regimes of domestic contract law. This may give rise to questions of conflict of laws, which can unfortunately not be addressed in this paper. ${ }^{16}$

\section{Incorporation of Standard Terms According to the CISG and the CESL}

\subsection{Introduction}

In commercial sales transactions, contracting parties often refer to standard terms and conditions. A trader which routinely sells goods to other traders will draft a set of standard terms and will (try to) use them for all sales. The question may arise how such standard terms can validly be incorporated in an international sales contract. This issue will be addressed in what follows, and a comparison between the CISG (section 3.2) and the CESL (section 3.3) will be made in this respect. Secondly, the solutions that the CISG and the CESL provide in case of a so-called battle of the forms will be discussed (section 3.4). ${ }^{17}$

\subsection{Incorporation of Standard Terms According to the CISG}

The CISG does not contain any express provisions on standard terms and conditions. At the time when the CISG was drafted, a proposal was made to expressly regulate the incorporation of general terms and condi-

14. Statement of the European Law Institute on the Proposal for a Regulation on a Common European Sales Law $\operatorname{COM(2011)~} 635$ final, approved by the ELI Council as an official Statement of the ELI on 7 September 2012, available at: <www.europeanlawinstitute.eu/fileadmin/ user_upload/p_eli/Publications/S-2-2012_Statement_on_the_Proposal_for_ a_Regulation_on_a_Common_European_Sales_Law.pdf> (last accessed on 16 July 2014). The report by the UK Law Commission, An Optional Common European Sales Law: Advantages and Problems, Advice to the UK Government, November 2011 is available at: <http:// lawcommission.justice.gov.uk/docs/Common_European_Sales_Law_ Advice.pdf> (last accessed on 16 July 2014).

15. The term 'digital content' is defined in Art. 2(j) of the Regulation on CESL. See also on the term 'digital content' Loos et al. 2011, pp. 729-758. The term 'related services' is defined in Art. $2(\mathrm{~m})$ of the Regulation on CESL.

16. See, in that regard, for example: Hesselink 2012, pp. 195-212; Whittaker 2012, pp. 578-605; Fornasier 2012, pp. 401-422 and Rühl 2012, pp. 148-163.

17. Compare on these issues also: Kruisinga 2013, pp. 341-362. tions in the Convention. This proposal was rejected, however, on the ground that the Convention already contained rules for the interpretation of the content of the contract. ${ }^{18}$ Thus, even though the CISG does not contain any special rules regarding the inclusion of standard terms in a contract, the CISG is applicable to this issue. This has been confirmed in case law and legal literature as well as by the CISG Advisory Council in its Opinion No. $13 .{ }^{19}$

Thus, the question whether any general terms and conditions were included in the contract needs to be answered on the basis of the provisions in the CISG dealing with the conclusion of contracts (Article 14 CISG ff.) and by applying the provisions on the interpretation of contracts (Article 8 CISG) and concerning usages (Article 9 CISG).$^{20}$ When determining whether a party's standard terms are validly incorporated in a sales contract, it needs to be ascertained, first of all, whether the standard terms were part of the offer which was the basis of the contract and which was accepted by the offeree (Article 14 CISG). It has to be determined whether, according to the understanding of a reasonable person of the same kind as the offeree, it was clear that the offeror intended to incorporate its general terms and conditions in the contract (Article 8(2) CISG). In its recently published Opinion No. 13, the CISG Advisory Council stated that if the offeror clearly informed the offeree that it wanted the contract to be subject to its standard terms, the standard terms will become part of their contract if the offeree accepts the offer, provided that the offeree had a reasonable opportunity to take notice of the contents of the standard terms.

In a case decided by the German Supreme Court (the Bundesgerichtshof), on 31 October 2001, it was held that it is required that the recipient of a contract offer that is intended to be based on standard terms has the possibility to become aware of these terms in a reasonable manner. ${ }^{21}$ The Bundesgerichtshof explicitly held that, according to the CISG, the offeror is required to transmit the text of the conditions to the offeree or to make the text of the conditions available in another way. The court explained, very clearly, the rationale of its decision. Firstly, it placed the burden of making the general terms and conditions available on the party using the standard terms because the recipient often cannot foresee which clauses he is agreeing to in a specific case due to the significant differences which exist between the standard terms used in different countries arising out of different national legal systems and customs. Secondly, the court held, for the party using standard terms, that it is easily possible to attach these terms to its offer.

18. See YB IX (1978) at 81, No. 278 and Schroeter 2010, pp. 275-276.

19. Schroeter 2010, pp. 275-276 and the decision by the German Supreme Court (Bundesgerichtshof) of 31 October 2001, 1 IHR 2002, pp. 14-16; the French Supreme Court (Cour de Cassation) of 16 July 1998, CLOUT No. 242; the Dutch Supreme Court (Hoge Raad) of 28 January 2005, NJ 2006, 517 and, for example, the decision by the US Court of Appeals for the Ninth Circuit 5 May 2003, 328 F.3d 528, 6 IHR 2003, pp. 295-296.

20. See Kruisinga 2013, pp. 349 et seq.

21. Bundesgerichtshof 31 October 2001,1 IHR 2002, pp. 14-16. 
The CISG-AC notes that this approach should be favoured. It states that "it is desirable that a party should make the standard terms available at the time of contracting" if the parties have not had prior dealings. In what manner should standard terms be made available in order to be validly incorporated in the contract? The so-called black letter rule No. 3 in the CISG Advisory Council's Opinion states that, amongst other things, a party is deemed to have had a reasonable opportunity to take notice of the standard terms:

(w)here the terms are attached to a document used in connection with the formation of the contract or printed on the reverse side of that document; (...) (w)here the terms are available to the parties in the presence of each other at the time of negotiating the contract; (...) (w)here, in electronic communications, the terms are made available to and retrievable electronically by that party and are accessible to that party at the time of negotiating the contract; (...) (w)here the parties have had prior agreements subject to the same standard terms.

\subsection{Incorporation of Standard Terms According to the CESL}

The CESL does not explicitly answer the question whether in $\mathrm{B} 2 \mathrm{~B}$ relations a mere reference to standard terms is sufficient to incorporate such terms in a contract. ${ }^{22}$ Article 70 CESL in the manner proposed by the European Commission contained a duty to raise awareness concerning standard contract terms. The second subsection of Article 70 CESL provided that contract terms were not sufficiently brought to the other party's attention by a mere reference thereto in a contract document. This part of the provision would only apply in relations between a trader and a consumer. If one uses an a contrario reasoning, it would follow from the CESL that in a commercial sales contract, the party using standard terms does not have to make the text of the conditions available to the other party. ${ }^{23}$ It may, however, confine itself to a mere reference to its standard terms in a contract document. Thus, it seems that Article 70 CESL in B2B transactions does not require that such terms be handed over to the other party. ${ }^{24}$ It could still be unclear what precisely was required; when has a trader taken reasonable steps to draw the other party's attention to the standard terms? This was a very important point as the provision in Article 70 CESL had a mandatory nature.

The provision in Article 70 CESL has been criticized, for example, by the European Law Institute in its aforementioned ELI Statement. The European Law Institute states that it is not 'apposite' to apply Article 70 CESL to both $\mathrm{B} 2 \mathrm{~B}$ and $\mathrm{B} 2 \mathrm{C}$ transactions as this is an issue of consumer protection, which should not be extended to

22. See also Kruisinga 2013, pp. 352 et seq.; Spanjaard \& Van Wechem 2012, p. 229.

23. See also Loos 2012, pp. 776-796.

24. See also Advocate General Wissink in Van Vliet/Dealkent, HR 11 May 2012, NJ 2012, 318. traders. In response to this criticism, the European Parliament amended this part of the Regulation, based upon the suggestion by the Legal Affairs Committee. It appeared sufficient to only provide for an obligation to raise awareness of standard contract terms in $\mathrm{B} 2 \mathrm{C}$ contracts. Thus, Article 70 CESL was deleted. Instead, the European Parliament inserted Article 76a, which applies only in B2C transactions. Article 76a provides that contract terms supplied by a trader may only be invoked against a consumer if the consumer was aware of them or if the trader took reasonable steps to draw the consumer's attention thereto, either before or when the contract was concluded. Thus, contract terms have to be presented in a way which is suitable to attract the attention of a consumer to their existence and made available in a manner which provides the consumer with an opportunity to comprehend them before the contract is concluded. Contract terms shall not be considered as having been sufficiently brought to the consumer's attention by a mere reference thereto in a contract document. The new version of the provision also indicates that it only has a mandatory nature in B2C contracts, as the fourth subsection of the new provision states that the parties may not, to the detriment of the consumer, exclude the application of this provision or derogate from, or vary, its effects.

\subsection{Battle of the Forms Solved According to the CISG and the CESL}

In case of a so-called battle of the forms, which is the situation in which both contracting parties use their own standard terms, the question may arise as to whether any of the standard terms used by both contracting parties can become a part of the contract. ${ }^{25}$ As the CISG does not contain any particular provisions concerning standard terms at all, a solution for such questions needs to be found in the provisions in the CISG on formation of contracts. A distinction needs to be made between the conclusion of the contract and determining the content of the contract. It is possible that a contract is concluded even though both contracting parties have used their own contradictory standard terms. ${ }^{26}$

It has been stated in the legal literature that questions which arise in case of a battle of the forms need to be answered by applying Article 19 CISG. A strict application of this provision would mean that the so-called last shot rule will apply. ${ }^{27}$ Article 19 CISG provides that a reply to an offer which intends to be an acceptance but contains additions, limitations or other modifications is a rejection of the offer and constitutes a counter-offer. If, however, such a reply does not materially alter the terms of the offer, it is not a rejection of the offer but constitutes an acceptance unless the offeror immediately objects to the differences. Which terms may be said to materially alter the terms of the offer? Article 19(3) CISG provides some examples of such terms; it refers to terms which relate to the price, payment, quality and

25. See Kruisinga 2013, pp. 356 et seq.

26. See also Schroeter 2010, pp. 350-351.

27. Schroeter 2010, pp. 348-349. 
quantity of the goods, the place and time of delivery, the extent of one party's liability towards the other or the settlement of disputes. This presumption can be rebutted in an individual situation.

General conditions usually contain provisions on either of these subjects; a seller will, for example, generally insert a forum selection clause in its standard terms. If the buyer's standard terms contain a different dispute settlement clause, the sets of general conditions will differ from each other. This means that an offer will be answered by a counter-offer, and this will finally imply that the contract is concluded at the time of performance (Article 18 CISG). From this, most scholars conclude that the last shot rule is applicable; the counter-offer that is sent last is decisive. In other words, the general conditions that were sent last become part of the contract. ${ }^{28}$

This interpretation of the CISG that leads to the application of the last shot rule has often been criticized in the legal literature. ${ }^{29}$ The choice for the application of the terms that were sent last seems to be coincidental, and one may question whether the offeree has indeed agreed to the standard terms of the offeror merely by performing the contract. Therefore, the CISG Advisory Council has opted for a different approach, the so-called knockout rule. To this end, black letter rule number ten of Opinion No. 13 states that

(w)here both parties seek to incorporate standard terms and reach agreement except on those terms, a contract is concluded on the basis of the negotiated terms and of any standard terms which are common in substance, unless one party clearly indicates in advance, or later on but without undue delay objects to the conclusion of the contract on that basis.

Thus, in case of a battle of the forms, the contract was concluded and contained all standard terms which were 'common in substance'. All other general conditions did not form part of the contract. The issues that were provided for in these other terms (which were 'knocked out') will be governed by the provisions in the national law or in the CISG, whichever is found to be applicable. The knock-out rule will not apply if a party clearly indicates that it does not intend to be bound by other standard terms than its own. According to the CISG-AC, it will not be sufficient in this context if the other party uses its own standard terms which provide that the conditions of the first party will not apply. An explicit declaration by the other party is required in its purported acceptance.

The more difficult question will be how to apply this knock-out rule if the standard terms of one party have no counterpart in the standard terms of the other party. ${ }^{30}$ Unfortunately, the CISG-AC does not spend many

28. See for example Meeusen 1997, pp. 93-94; Ferrari 2011, pp. 289-290 and Schroeter 2010, pp. 348-349.

29. Compare, for example, Ventsch \& Kluth 2003, pp. 63-64 and Meeusen 1997, p. 94.

30. See Kruisinga 2013, pp. 360 et seq. words on this issue in its Opinion. It merely states that in determining which parts are 'common in substance' and which parts conflict, a court should consider the standard terms as a whole and should not consider clauses in isolation. To me, the term 'common in substance' would mean that both parties must have a similar provision in their standard terms concerning the particular issue. It is only in these cases that the parties in fact reached agreement on this subject. This position was also taken, albeit using a different name, by Schroeter, before the Opinion by the CISG-AC was published. Schroeter $^{31}$ stated that in the application of the CISG, the rest validity theory should apply. He concludes that "the terms that the parties agreed upon (...) in the standard forms which do not contradict each other become part of the contract". In reply to the question of when such a contradiction arises, Schroeter ${ }^{32}$ states that such a contradiction even exists where the terms of one party deal with matters on which the other party's terms are silent. He states that there will be a contradiction in such cases since the other party's declaration must then be supplemented by the - typically different - rules of the CISG.

The knock-out rule can also be found in Article 39 of the CESL which provides that where the parties have reached agreement except that the offer and acceptance refer to conflicting standard contract terms, a contract is nonetheless concluded. ${ }^{33}$ The standard contract terms are part of the contract to the extent that they are 'common in substance'. Thus, according to the CESL, the same question arises so as to determine whether terms are 'common in substance' and how to deal with additional terms. With regard to this latter question, DiMatteo $^{34}$ distinguishes two possible solutions: (1) this is not a case of conflict and the term becomes part of the contract as long as it does not materially alter the terms of the offer within the meaning of Article $38 \mathrm{CESL}$, or (2) this is a conflicting term and thus the additional terms will not become part of the contract. $\operatorname{Loos}^{35}$ has advocated the first approach; it is his position that if the standard terms of one party regulate a particular issue and the other party's terms remain silent on this topic, the relevant terms have become part of the contract. One may wonder, however, if the relevant terms will in such a case indeed be 'common in substance'.

31. Schroeter 2010, pp. 354-355

32. Schroeter 2010.

33. Article 39 CESL reads: "1. Where the parties have reached agreement except that the offer and acceptance refer to conflicting standard contract terms, a contract is nonetheless concluded. The standard contract terms are part of the contract to the extent that they are common in substance. 2. Notwithstanding paragraph 1, no contract is concluded if one party: (a) has indicated in advance, explicitly, and not by way of standard contract terms, an intention not to be bound by a contract on the basis of paragraph 1; or (b) without undue delay, informs the other party of such an intention.'

34. DiMatteo 2012, p. 48.

35. Loos 2012, Section III.1. 


\section{International Sale of Goods and Brussels I}

As will be addressed in more detail in the contribution by Dr. Rammeloo, the EU Regulation on jurisdiction and the recognition and enforcement of judgments in civil and commercial matters (also referred to as Brussels I) ${ }^{36}$ provides which courts have jurisdiction in international contracts. Article 2 Brussels I provides that persons domiciled in a Member State shall be sued in the courts of that state. Thus, the court of the place of business of the defendant will generally have jurisdiction if this is within a Member State. In addition, Article 5 Brussels I contains an alternative ground for jurisdiction in case of a dispute concerning an international contract. It provides that in matters relating to a contract, a (legal) person domiciled in a Member State may be sued in another Member State in the courts for the place of performance of the obligation in question.

The Brussels Convention 1968 on jurisdiction and the enforcement of judgments in civil and commercial matters, which preceded the Brussels I Regulation, contained a very similar provision in Article 5(1). Thus, if a dispute arose concerning the payment of the purchase price in a contract that was governed by the CISG, the place of performance was determined by the application of Article 57 CISG. In a dispute concerning the delivery of goods, the place of performance was determined by Article 31 CISG. ${ }^{37}$ In 2000, the Brussels Convention was changed into an EU Regulation, the Brussels I Regulation. When the Brussels I Regulation was introduced, parts of Article 5 were amended. Article 5(1)(b) Brussels I provides, and this part of the provision was newly introduced in the Brussels I Regulation, that for the purposes of this provision, and unless otherwise agreed, the place of performance of the obligation in question shall, in the case of the sale of goods, be the place in a Member State where, under the contract, the goods were delivered or should have been delivered. This means that jurisdiction for all disputes concerning the contractual obligations of both seller and buyer is uniformly granted to the court of the place of delivery.

The case law of the European Court of Justice ${ }^{38}$ illustrates that in order to determine the place of delivery on the basis of the provisions of the contract within the meaning of Article 5 Brussels I, any agreed Incoterms are of importance. The ECJ held that the court must take into account all the relevant terms and clauses in that contract, including "terms and clauses generally recognized and applied in international commercial usage, such as the Incoterms, in so far as they enable

36. Council Regulation (EC) No. 44/2001 of 22 December 2000 on jurisdiction and the recognition and enforcement of judgments in civil and commercial matters (OJ 2000 L12, p. 1).

37. See Kruisinga 2014, pp. 497 et seq.

38. European Court of Justice 9 June 2011, Case C-87/10 (Electrosteel). See also Kruisinga 2014, pp. 497 et seq. that place to be clearly identified". It added that where a contract contains such terms or clauses

it may be necessary to examine whether they are stipulations which merely lay down the conditions relating to the allocation of the risks connected to the carriage of the goods or the division of costs between the contracting parties, or whether they also identify the place of delivery of the goods.

For contracts for the international sale of goods that are governed by the CISG, the question arose whether, if no place of delivery had been agreed upon, the place of delivery would have to be determined on the basis of Article 31 CISG. The European Court of Justice ${ }^{39}$ answered this question in the negative with regard to international sales contracts that involve carriage of the goods. It held that Article 5(1)(b) Brussels I must be interpreted as meaning that

in the case of a sale involving carriage of goods, the place where, under the contract, the goods sold were delivered or should have been delivered must be determined on the basis of the provisions of that contract. Where it is impossible to determine the place of delivery on that basis, without reference to the substantive law applicable to the contract, that place is the place where the physical transfer of the goods took place, as a result of which the purchaser obtained, or should have obtained, actual power of disposal over those goods at the final destination of the sales transaction.

Even though this definition includes a number of relevant criteria, such as the physical transfer of the goods and the actual power of disposal at the final destination, there will still be cases in which this definition may be difficult to apply. This will, for example, be the case if the buyer and seller have not agreed upon a particular place of delivery and the goods are delivered immediately to a third purchaser in another country.

\section{Conclusion}

When drafting a contract for the international sale of goods, one should take into account that it is important to expressly provide which law will be applicable. Nowadays, that can generally be either a particular national law, or the CISG. If the Regulation on CESL enters into force, an additional option is offered. Contracting parties within the EU will in that case, generally, be entitled to choose between the CISG, the CESL and national law. Thus, even more accurate attention will then have to be paid to the agreement on the applicable law.

Questions concerning standard terms are provided for in a different manner in the CISG and the CESL.

39. European Court of Justice 25 February 2010, Case C-381/08 (CarTrim). 
Thus, for a contracting party to rely on its standard terms, it has to be ascertained whether those standard terms were validly incorporated in the contract. As far as the CISG is concerned, numerous questions have been answered by the CISG Advisory Council in its Opinion No. 13 on the incorporation of standard terms. However, not all issues have been solved.

Will the CESL offer any benefit for contracts for the international sale of goods? As the CISG Advisory Council has stated in its recent Declaration on the CISG and regional harmonization, while also explicitly referring to the CISG and CESL, "the existence of a global and regional sales law, in addition to the two national laws of the contracting parties, would certainly have a complicating impact on the pre-contractual process". 40 Thus, there is never a dull moment in the field of contracts for the international sale of goods.

\section{Bibliography}

L.A. DiMatteo, "The Curious Case of Transborder Sales Law: A Comparative Analysis of CESL, CISG and the UCC", in U. Magnus (ed.), CISG vs. Regional Sales Lam Unification, Munich, Sellier European Law Publishers 2012.

F. Ferrari, in S. Kröll et al. (eds.), UN Convention on Contracts for the International Sale of Goods (CISG), Munich, Beck 2011.

M. Fornasier, "28. versus 2. Regime - Kollisionsrechtliche Aspekte eines optionalen europäischen Vertragsrecht", 76 RabelsZ Bd 2012.

M. Hesselink, "How to Opt into the Common European Sales Law? Brief Comments on the Commission's Proposal for a Regulation", 1 European Reviem of Private Law 2012.

E.M. Kieninger, „Allgemeines Leistungsstörungsrecht im Vorschlag für ein Gemeinsames Europäisches Kaufrecht", in H. Schulte-Nölke et al. (eds.), Der Entwurf für ein optionales europäisches Kaufrecht, Munich, Sellier European Law Publishers 2012.

N. Kornet, "The Common European Sales Law and the CISG Complicating or Simplifying the Legal Environment?", 19 Maastricht Fournal of European and Comparative Lam 2012.

S.A. Kruisinga, "Incorporation of Standard Terms According to the CISG and the CESL: Will these Competing Instruments Enhance Legal Certainty in Cross-Border Sales Transactions?", 24 European Business Lam Reviem 3, 2013.

S.A. Kruisinga, "The Global Challenge of International Sales Law, Country Analysis: the Netherlands", in L.A. DiMatteo (ed.), The Global Challenge of International Sales Law, Cambridge, Cambridge University Press 2014.

O. Lando, "Comments and Questions Relating to the European Commission's Proposal for a Regulation on a Common European Sales Law”, 6 European Reviem of Private Lam 2011.

M. Loos, N. Helberger, L. Guibault \& C. Mak, "The Regulation of Digital Content Contracts in the Optional Instrument of Contract Law", 6 European Reviem of Private Law 2011.

M.B.M. Loos, "Standard Contract Terms Regulation in the Proposal for a Common European Sales Law", Zeitschrift für Europäisches Privatrecht 2012.
P. Mankowski, “CESL - Who Needs It?”, 2 Internationales Handelsrecht 2012.

J. Meeusen, "Totstandkoming van de overeenkomst", in H. Van Houtte et al. (eds.), Het Weens Koopverdrag, Antwerp, Intersentia 1997.

L. Mistelis, in S. Kröll et al. (eds.), UN Convention on Contracts for the International Sale of Goods (CISG) Commentary, Munich, C.H. Beck 2011.

B. Piltz, "The Proposal for a Regulation on a Common European Sales Law and More Particular its Provisions on Remedies", 4 Internationales Handelsrecht 2012.

G. Rühl, "The Common European Sales Law: 28th Regime, 2nd Regime or 1st Regime?", 1 Maastricht Fournal of European and Comparative Lam 2012.

P. Schlechtriem \& P. Butler, UN Law on International Sales, Heidelberg, Springer-Verlag 2009.

U.G. Schroeter, in I. Schwenzer (ed.), Schlechtriem \& Schmenzer Commentary on the UN Convention on the International Sale of Goods (CISG), Oxford, Oxford University Press 2010.

I. Schwenzer \& P. Hachem, in I. Schwenzer (ed.), Schlechtriem E Schmenzer Commentary on the UN Convention on the International Sale of Goods (CISG), Oxford, Oxford University Press 2010.

J.H.M. Spanjaard \& T.H.M. van Wechem, “Algemene voorwaarden in het GEKR in vergelijking met het Nederlandse BW", 7/8 Maandblad voor Vermogensrecht 2012.

V. Ventsch \& P. Kluth, „Die Einbeziehung van Allgemeinen Geschäftsbedingungen im Rahmen des UN-Kaufrechts", 2 Internationales Handelsrecht 2003.

S. Whittaker, "The Proposed Common European Sales Law: Legal Framework and the Agreement of the Parties", 75 Modern Law Reviem 4, 2012. 